\title{
Perencanaan dan Pengeloalaan Keuangan Keluarga pada Ibu Rumah Tangga Dusun Pasekan Lor, Balecatur, Gamping, Sleman, Yogyakarta
}

\author{
Ika Wulandari ${ }^{1}$ \\ Universitas Mercu Buana Yogyakarta, ikawulandari@mercubuana-yogya.ac.id \\ Endang Sri Utami ${ }^{2}$ \\ Universitas Mercu Buana Yogyakarta, endang@mercubuana-yogya.ac.id
}

\begin{abstract}
Abstrak
Kegiatan pengabdian kepada masyarakat ini dilakukan di dusun Pasekan Lor, Balecatur, Gamping, Sleman, Yogyakarta dengan tema penyuluhan perencanaan dan pengelolaan keuangan keluarga ibu rumah tangga Dasawisma VII. Ibu rumah tangga mempunyai posisi penting sebagai pengatur keuangan keluarga. Latar belakang pelaksanaan kegiatan dikarenakan tingkat pemahaman mitra sasaran terhadap pentingnya perencanaan dan cara melakukan pengelolaan keuangan keluarga yang masih tergolong rendah. Mitra sasaran juga belum memahami pentingnya berinvestasi untuk meningkatkan pendapatan keluarga. Tujuan penyuluhan ini untuk memberikan pemahaman dan pengetahuan mengenai pentingnya perencanaan keuangan dan bagaimana melakukan pengelolaan keuangan yang baik di lingkungan keluarga. Pelaksanaan pengabdian ini diikuti oleh 22 peserta pada tanggal 28 Juli 2019. Metode yang digunakan adalah penyuluhan, diskusi dan tanya jawab. Kegiatan terlaksana dengan baik hal ini dibuktikan dengan antusiasme peserta dalam mengikuti penyuluhan dari awal sampai akhir. Setelah dilakukan penyuluhan sebanyak $91 \%$ dari peserta penyuluhan memahami dan mengetahui cara melakukan perencanaan dan pengelolaan keuangan keluarga dengan cukup baik. Sebelum dilakukan penyuluhan hanya $9 \%$ dari peserta yang sudah melakukan perencanaan keuangan dengan baik dan terstruktur, setelah dilakukan sosialisasi jumlahnya meningkat menjadi $73 \%$.
\end{abstract}

Kata kunci : Dasawisma, Balecatur, Penyuluhan, Keuangan Keluarga

\begin{abstract}
Community service activities were carried out in Pasekan Lor, Balecatur, Gamping, Sleman, Yogyakarta with the theme of financial planning and management of Dasawisma VII housewives' families. Housewives have an important position as a regulator of family finances. The background to the implementation of activities related to the targets' financial assistance planning is still relatively low and also have not been successful. The purpose of this discussion is to provide understanding and knowledge about financial planning and how to manage finances well in the Family Environment. Implementation of this service was attended by 22 participants on July 28, 2019. The method used was discussion, and question and answer. This activity was carried out well as evidenced by the enthusiasm of the participants from beginning to the end. After counseling, the $91 \%$ of the participants
\end{abstract}


understand how to plan and manage family finances fairly well. Before counseling, only 9\% of participants had financial planning that was well structured, after the socialization the amount had been increased to $73 \%$

Keywords: Dasawisma, Balecatur, Counseling, Family Finance

\section{Pendahuluan}

Dusun Pasekan Lor merupakan salah satu dusun yang terletak di wilayah Desa Balecatur, Kecamatan Gamping, Kabupaten Sleman, Yogyakarta. Dusun Pasekan Lor berbatasan dengan dusun Nyamplung di wilayah Utara, Dusun Sumber Gamol di wilayah Barat, Dusun Pasekan Kidul di wilayah Selatan dan desa Ambarketawang di wilayah Timur. Secara geografis, dusun Pasekan Lor mempunyai lahan yang subur sehingga cocok digunakan untuk lahan pertanian. Walaupun demikian mata pencaharian warga di dusun ini cukup bervariasi, mulai dari petani, buruh tani, pegawai negeri sipil, profesional, wirasawasta dan sebagainya. Dengan kondisi alam yang subur ternyata tidak menjamin terjadinya peningkatan ataupun pemerataan pendapatan yang baik di daerah tersebut.

Menurut Lestari (2012) keluarga adalah rumah tangga yang memiliki hubungan darah atau perkawinan atau menyediakan terselenggaranya fungsi-fungsi instrumental mendasar dan fungsi-fungsi ekspresif keluarga bagi para anggotanya yang berada dalam satu jaringan. Keluarga memegang peranan penting dalam kegiatan ekonomi suatu negara, karena rumah tangga berperan tidak hanya sebagai konsumen tetapi juga dapat berperan sebagai produsen. Rumah tangga dalam peranannya sebagai konsumen tidak terlepas dari banyaknya pengeluaran rutin yang digunakan untuk mencukupi kebutuhannya. Hal ini dimaksudkan agar suatu keluarga dapat hidup dengan layak. Penghasilan atau pendapatan keluarga menjadi faktor kunci untuk menunjang kegiatan konsumsi tersebut. Penghasilan keluarga bersumber dari gaji, upah, keuntungan dari transaksi, investasi atau pendapatan lain di luar penghasilan utama.

Sebagian besar penghasilan dalam suatu keluarga dialokasikan untuk pengeluaran rumah tangga seperti mencukupi kebutuhan primer, kegiatan sosial, hiburan dan lainnya. Selain itu penghasilan harus dialokasikan untuk menabung atau berinvestasi, dana tabungan dapat digunakan jika terdapat kebutuhan yang mendesak atau mendadak. Pengeluaran rumah tangga juga dapat dibedakan menjadi pengeluaran harian, bulanan dan tahunan. Pengeluaran harian berhubungan dengan kebutuhan sehari-hari misal untuk makan dan minum, sedangkan pengeluaran bulanan adalah pengeluaran yang dilakukan satu bulan sekali. Contoh pengeluaran bulanan adalah pengeluaran untuk membayar listrik, air, asuransi, iuran sekolah anak. Sedangakan pengeluaran tahunan hanya dilakukan setiap satu tahun sekali, misalkan membayar pajak kendaraan. 
Menurut Siagian (2008), perencanaan merupakan keseluruhan proses pemikiran dan penentuan secara matang pada hal-hal yang akan dikerjakan di masa mendatang dalam rangka pencapaian yang sudah ditentukan. Keuangan merupakan ilmu dan seni dalam mengelola uang yang mempengaruhi kehidupan setiap orang dan setiap organisasi. Keuangan berhubungan dengan proses, lembaga, pasar, dan instrumen yang terlibat dalam transfer uang diantara individu maupun antara bisnis dan pemerintah (Ridwan dan Inge, 2003). Jadi perencanaan keuangan keluarga merupakan suatu keahlian untuk merencanakan dan mengatur keuangan keluarga sehingga jumlah kebutuhan dan pengeluaran keluarga menjadi lebih jelas. Dengan adanya perencanaan keuangan keluarga yang baik memungkinkan anak-anak untuk mendapatkan pendidikan yang baik, kesehatan yang terjamin dan tersedianya sarana dan prasarana lain yang mendukung. Perencanaan keuangan keluarga dapat dikelompokkan menjadi tiga yaitu perencanaan keuangan jangka pendek, jangka menengah dan jangka panjang. Perencanaan keuangan keluarga jangka pendek merupakan perencanaan keuangan dengan jangka waktu pemenuhan kebutuhan kurang dari 1 tahun. Perencanaan keluarga jangka menengah merupakan perencanaan keuangan dengan jangka waktu pemenuhan kebutuhan antara 1 sampai 3 tahun. Perencanaan keluarga jangka panjang direncanakan dengan jangka waktu pemenuhan kebutuhan di atas 5 tahun.

Menurut Bank Indonesia (2013) pengelolaan keuangan didefinisikan sebagai sebuah tindakan untuk mencapai tujuan keuangan di masa yang akan datang. Pengelolaan keuangan meliputi pengelolaan keuangan pribadi, pengelolaan keuangan keluarga, dan pengelolaan keuangan perusahaan. Pengelolaan keuangan merupakan bagian penting dalam mengatasi masalah ekonomi, baik masalah ekonomi individu, keluarga maupun perusahaan. Langkah-langkan dalam pengelolaan keluarga menurut Bank Indonesia (2013) adalah a). Melakukan pencatatan aset/ harta yang dimiliki, b). melakukan pencatatan semua pemasukan dan pengeluaran, c). mengidentifikasi pengeluaran rutin, bulanan dan tahunan dan d). menyusun rencana pengeluaran (budgetting).

Peran ibu rumah tangga dalam keluarga tidak hanya sekedar mengurus suami, anak dan keperluan rumah tangga tetapi juga berperan untuk mengatur keuangan atau ekonomi keluarga. Sebesar apapun jumlah pendapatan atau penghasilan keluarga jika tidak didukung dengan perencanaan dan pengelolaan keuangan yang baik maka hasilnya juga tidak efisien. Ketidakmampuan melakukan perencanaan dan pengelolaan keuangan dapat mengakibatkan pengeluaran yang lebih besar dari jumlah penghasilan. Jika antara pengeluaran dan penghasilan tidak seimbang atau bahkan jumlah pengeluaran lebih tinggi dari penghasilan, maka akan menimbulkan utang. Utang jika tidak dikelola dengan baik justru akan memperburuk kondisi keuangan keluarga. Kondisi keuangan keluarga yang tidak stabil dapat memicu terjadinya konflik keluarga. Apalagi jika diikuti dengan peningkatan harga kebutuhan rumah tangga dan kurangnya pemahaman dalam melakukan perencanaan dan pengelolaan keuangan. 
Perencanaan dan pengelolaan keuangan keluarga yang baik belum dilakukan secara maksimal oleh ibu rumah tangga kelompok Dasawisma VII di dusun Pasekan Lor. Kondisi ini terlihat dari kegiatan arisan atau pertemuan rutin yang melibatkan simpan pinjam di dalamnya. Beberapa warga tidak mampu membayar utang pada saat sudah jatuh tempo dan tidak membayar iuran wajib dengan berbagai alasan, salah satuya adalah tidak tersedianya dana yang cukup. Kondisi seperti ini memungkinkan terjadinya konflik antar warga. Konflik yang berkepanjangan dan tanpa solusi yang baik dapat menimbulkan perpecahan antar warga. Hal ini tentunya berdampak terhadap stabilitas ketenteraman dan kenyamanan dalam bermasyarakat.

Secara umum pengelolaan keuangan keluarga merupakan suatu tindakan yang diambil oleh pengatur keuangan rumah tangga untuk mencapai tujuan keuangan di masa yang akan datang. Tujuan dari pengelolaan keuangan keluarga adalah mencapai target di masa yang akan datang, melindungi dan meningkatkan kekayaan yang dimiliki, mengatur arus kas, mengelola utang dan piutang dan mengatur dana untuk berinvestasi. Beberapa masyarakat khususnya di daerah pedesaan masih belum paham tentang pentingnya berinvestasi, sehingga perlu diberikan pemahaman yang lebih tentang manfaat melakukan investasi. Jenis investasi yang dilakukan oleh masyarakat di dusun Pasekan Lor masih kurang bervariatif. Kecenderungan masyarakat pedesaan berinvestasi terbatas pada emas atau tanah, sedangkan investasi lain seperti saham, obligasi, reksadana atau deposito belum begitu dikenal dengan baik.

Semakin besar penghasilan suatu keluarga tidak menjamin terpenuhinya semua kebutuhan, hal ini disebabkan masih terdapat keluarga yang mengalami defisit keuangan di akhir bulan. Jadi permasalahan pokok yang mendasar adalah bukan besar kecilnya suatu penghasilan atau pendapatan, namun seberapa pandai suatu keluarga khususnya ibu rumah tangga mengatur pengeluaran termasuk dalam hal ini merencanakan dan mengelola keuangan keluarga. Berdasarkan uraian tersebut, maka perlu dilakukan penyuluhan dalam hal perencanaan dan pengelolaan keluarga di dusun Pasekan Lor, Balecatur, Gamping untuk mengatasi beberapa permasalahan serta dampak yang mungkin terjadi. Mitra sasaran adalah ibu rumah tangga kelompok Dasawisma VII Pasekan Lor.

Tujuan dari kegiatan Pengabdian kepada masyarakat ini adalah untuk meningkatkan pengetahuan dan kemampuan tentang perencanaan dan pengelolaan keuangan bagi ibu rumah tangga kelompok Dasawisma VII di dusun Pasekan Lor, Balecatur, Gamping pada khususnya.

\section{Metode}

Metode yang digunakan dalam kegiatan pengabdian kepada masyarakat ini berupa penyuluhan, diskusi dan tanya jawab. Pada kegiatan penyuluhan dijelaskan tentang 
jenis-jenis perencanaan keluarga, manfaat penting dari perencanaan keuangan keluarga dan bagaimana mengelola keuangan yang baik. Selain itu juga disampaikan upaya yang dapat dilakukan oleh ibu rumah tangga untuk membantu meningkatkan pendapatan keluarga, salah satunya dengan cara berinvestasi atau melakukan kegiatan produktif lainnya. Dalam kegiatan pengabdian ini melibatkan anggota kelompok ibu rumah tangga Dasawisma VII, Dusun Pasekan Lor, Desa Balecatur, Kecamatan Gamping, Kabupaten Sleman, Daerah Istimewa Yogyakarta. Jumlah ibu rumah tangga secara keseluruhan adalah sebanyak 31 orang. Pada sesi penyuluhan jumlah peserta yang hadir sebanyak 22 orang.

\section{Hasil dan Pembahasan}

Kegiatan Pengabdian masyarakat ini diselenggarakan atas kerjasama LPPM Universitas Mercu Buana Yogyakarta dengan Kelompok Ibu-ibu Dasawisma VII, Pasekan Lor, Balecatur, Gamping, Sleman Yogyakarta. Kegiatan penyuluhan ini dilaksanakan pada tanggal 28 Juli 2019 bertempat di Rt 04/04 Pasekan Lor Balecatur Gamping Sleman. Secara umum kegiatan yang dilakukan lancar tanpa terkendala apapun. Kegiatan ini direncanakan dihadiri oleh 31 peserta, namun pada hari pelaksanaan hanya dihadiri oleh 22 ibu rumah tangga anggota Kelompok Dasawisama VII Pasekan Lor.

Tahap kegiatan pengabdian kepada masyarakat ini meliputi tahap persiapan, tahap pelaksanaan dan tahap evaluasi. Pada tahap persiapan meliputi perizinan dari Ketua RT setempat, pembuatan materi, pembuatan dan penyampaian undangan, pembuatan spanduk, persiapan dokumen dan sarana prasarana pendukung. Pada tahap persiapan dilakukan koordinasi antara narasumber dan ketua kelompok Dasawisma VII Pasekan Lor mengenai tanggal dan tempat pelaksanaan. Pada tahap kedua yaitu pelaksanaan kegiatan, tim pengabdi memberikan penyuluhan, membimbing praktik, diskusi dan tanya jawab. Acara kegiatan dilaksanakan mulai pukul 09.00 s.d 12.00 WIB. Tahap terakhir dilakukan evaluasi penyuluhan dengan memberikan beberapa pertanyaan terkait materi yang sudah disampaikan. Selain itu juga dilakukan pemantauan pasca kegiatan peyuluhan.

Tahap pelaksanaan kegiatan meliputi sesi pembukaan, sesi penyampaian materi, sesi praktik, tanya jawab, diskusi, sesi lain lain dan penutup. Sesi pembukaan diawali dengan menyanyikan lagu Indonesia Raya dan berdoa bersama dipimpin oleh Ketua tim pengabdi. Sebelum sesi penyampaian materi, pertama kali disampaikan maksud dan tujuan dilaksanakannya kegiatan pengabdian. Tim pengabdi juga menyampaikan lembaga yang mendanai kegiatan yaitu LPPM UMBY.

Pada sesi utama yaitu penyampaian materi dilakukan secara bergantian oleh tim pengabdi. Sesi ini meliputi 2 tahap yaitu tahap I penyuluhan dengan tema "Cara merencanakan, mengatur, mengelola keuangan keluarga dan cara meminimalkan risiko utang". Sedangkan tahap II dengan Tema "Peningkatan pendapatan keluarga melalui investasi". Setelah tahap II selesai, dilanjutkan dengan sesi praktik yaitu berlatih melakukan perencanaan dan pengelolaan keuangan keluarga yang disesuaikan dengan kondisi ekonomi masing-masing peserta.

Garis besar materi yang disampaikan pada penyuluhan tahap I adalah bahwa 
perencanaan keuangan keluarga merupakan hal yang penting dilakukan dalam setiap keluarga. Cara merencanakan keuangan antara keluarga yang mempunyai utang dengan yang tidak mempunyai utang berbeda. Alokasi penghasilan untuk keluarga yang mempunyai utang meliputi alokasi pembayaran cicilan utang, menabung atau berinvestasi, memenuhi kebutuhan harian atau rutin, melakukan kegiatan sosial dan sebagian dialokasikan untuk bersenang-senang atau hiburan. Besarnya alokasi penghasilan untuk masing-masing pos adalah untuk membayar utang maksimal sebesar $30 \%$ dari penghasilan, $15 \%$ untuk berinvestasi atau menabung, $40 \%$ untuk memenuhi kebutuhan utama atau rutin, minimal 5\% untuk kegiatan sosial dan maksimal 10\% dari penghasilan untuk kegiatan hiburan atau bersenang-senang. Alokasi ini dapat disesuaikan jika jumlah utang ternyata lebih rendah dari 30\% penghasilan, maka sisanya dapat dialokasikan untuk menambah kebutuhan lain, misalkan ditambahkan pada kegiatan menabung/investasi. Sedangkan untuk keluarga yang tidak mempunyai utang maka pos untuk membayar cicilan utang dihilangkan sehingga alokasi untuk pos lainnya bisa menjadi lebih besar. Misalkan 50\% untuk kebutuhan harian, $30 \%$ untuk menabung/ berinvestasi, 7,5\% untuk kegiatan sosial dan 12,5\% untuk hiburan.

Pada penyuluhan tahap II disampaikan materi mengenai cara dan jenis investasi. Selain emas dan tanah terdapat investasi lain seperti deposito di bank, saham, obligasi dan reksadana. Sebagai pengatur dan perencana keuangan keluarga, ibu rumah tangga di dusun Pasekan Lor belum begitu paham akan pentingnya berinvestasi. Setiap investasi mempunyai risiko tersendiri. Investasi dalam bentuk emas mempunyai risiko kehilangan dan turunnya harga emas. Investasi dalam bentuk tanah mempunyai risiko tidak mudah untuk segera dicairkan dalam bentuk uang tunai ketika pemilik tanah memerlukan dana. Hal ini dikarenakan untuk proses jual beli tanah memerlukan waktu yang reltif lama. Salah satu alternatif investasi yang dapat dilakukan oleh ibu rumah tangga adalah dalam bentuk deposito berjangka. Meskipun deposito berjangka merupakan salah satu kategori simpanan, namun deposito berjangka dapat dianggap sebagai salah satu bentuk investasi. Hal ini dikarenakan deposito berjangka menawarkan suku bunga yang lebih tinggi setiap tahunnya dibandingkan jenis simpanan lainnya. Namun demikian, deposito berjangka juga mempunyai kelemahan, yaitu adanya penalty ketika nasabah mengambil dananya sebelum jatuh tempo. Sedangkan investasi dalam bentuk saham mempunyai risiko terjadinya capital loss dan tidak diterimanya deviden ketika terjadi kerugian. Investasi dalam bentuk obligasi juga memiliki risiko terjadinya capital loss. Capital loss terjadi ketika harga jual surat berharga lebih rendah dibandingkan harga beli. Jenis investasi ini asing bagi sebagian besar peserta, selain itu tingkat pemahaman mengenai saham dan obligasi yang masih rendah diikuti risiko yang tinggi, maka investasi jenis ini belum menjadi pilihan bagi ibu rumah tangga dusun Pasekan Lor. Bagi ibu rumah tangga yang berminat berinvestasi dalam bentuk surat berharga tetapi mempunyai keterbatasan pengetahuan dan dana dapat memilih alternatif untuk mengikuti reksadana.

Pada sesi praktik, peserta penyuluhan diberikan kesempatan untuk melakukan perencanaan keuangan dengan menggunakan asumsi sesuai penghasilan masingmasing keluarga dan bagaimana mengalokasikan penghasilan tersebut ke pos-pos 
pengeluaran keluarga. Pada sesi ini peserta dibantu untuk melakukan penghitungan dan perencanaan oleh narasumber. Sebagai ilustrasi suatu keluarga mempunyai penghasilan sebesar $\mathrm{Rp} 5.000 .000,00$ dan mempunyai utang, maka alokasi penghasilan yang ideal adalah maksimal $\mathrm{Rp}$ 1.500.000,00 digunakan untuk membayar utang, Rp 750.000,00 untuk menabung/berinvestasi, maksimal Rp 2.000.000,00 untuk membiayai kebutuhan rutin, Rp 250.000,00 untuk kegiatan sosial, sisanya Rp 500.000,00 untuk kebutuhan harian.

Pada sesi diskusi dan tanya jawab terdapat beberapa pertanyaan yang diajukan oleh peserta seperti cara mengelola tabungan, bagaimana menyelesaikan utang, jenis tabungan di bank, bagaimana tips merencanakan keuangan keluaraga secara efektif. Antusiasme peserta dalam mengajukan pertanyaan, menunjukkan minat yang tinggi terhadap kegiatan yang dilakukan. Pada sesi ini terdapat umpan balik yang baik antara tim pengabdi dan peserta dengan memberikan jawaban yang sesuai. Sesi selanjutnya adalah sesi lain-lain yang diisi dengan pembagian doorprize bagi peserta yang mampu menjawab pertanyaan seputar materi penyuluhan. Pada sesi penutup ditutup oleh Ketua Tim Pengabdi. Berikut dokumentasi kegiatan penyuluhan :

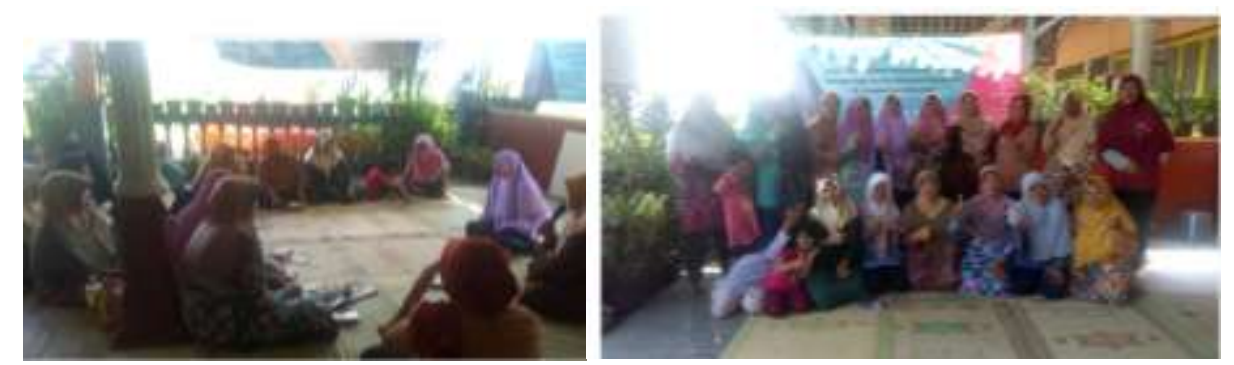

Gambar 1. Dokumentasi Kegiatan Penyuluhan

Setelah pelaksanaan penyuluhan, dilakukan evaluasi dengan cara pemantauan secara berkala. Pada tahap evaluasi ibu rumah tangga kelompok Dasawisma VII, memberikan informasi terkait kegiatan perencanaan dan pengelolaan keuangan keluarga yang sudah dilakukan pasca kegiatan penyuluhan.

Sebagai indikator keberhasilan dari kegiatan penyuluhan, disajikan dalam tabel berikut :

Tabel 1

Indikator Keberhasilan Kegiatan Penyuluhan

\begin{tabular}{clcc}
\hline No & \multicolumn{1}{c}{ Keterangan } & $\begin{array}{c}\text { Sebelum } \\
\text { Penyuluhan }\end{array}$ & $\begin{array}{c}\text { Setelah } \\
\text { Penyuluhan }\end{array}$ \\
\hline 1 & $\begin{array}{l}\text { Peserta yang memahami pentingnya } \\
\text { perencanan keuangan keluarga }\end{array}$ & $36 \%$ & $100 \%$ \\
2 & $\begin{array}{l}\text { Peserta yang mengetahui cara } \\
\text { melakukan perencanaan dan } \\
\text { pengelolaan keuangan keluarga }\end{array}$ & $36 \%$ & $91 \%$ \\
3 & $\begin{array}{l}\text { Peserta yang sudah melakukan } \\
\text { perencanaan keuangan keluarga dengan } \\
\text { baik }\end{array}$ & $9 \%$ & $73 \%$ \\
\hline
\end{tabular}

Sebelum dilakukan penyuluhan hanya sekitar 36\% dari peserta penyuluhan yang memahami pentingnya melakukan perencanaan dan pengelolaan keuangan 
keluarga, setelah penyuluhan jumlahnya meningkat menjadi $100 \%$. Sebelum penyuluhan hanya sebanyak $36 \%$ dari peserta yang mengetahui bagaimana cara melakukan perencanaan keluarga dan setelah penyuluhan jumlah ini meningkat menjadi $91 \%$. Setelah penyuluhan anggota kelompok menjadi paham tentang pentingnya perencanaan keuangan keluarga, mengetahui bagaimana cara mengalokasikan penghasilan dan prioritas apa saja yang harus didahulukan. Sebelum dilakukan penyuluhan hampir $91 \%$ dari jumlah peserta tidak melakukan perencanaan keuangan keluarga dengan baik dan terstruktur, hal ini disebabkan karena ketidaktahuan atau keengganan untuk melaksanakan kegiatan tersebut. Setelah penyuluhan sekitar $73 \%$ dari peserta penyuluhan sudah mulai melakukan perencanaan dan pengelolaan keuangan keluarga dengan baik. Data ini diperoleh melalui kegiatan evaluasi secara berkala setelah dilakukannya penyuluhan

\section{Simpulan dan Rekomendasi}

Dengan suksesnya kegiatan penyuluhan yang sudah dilaksanakan dan melihat antusiasme peserta penyuluhan, maka rencana tindak lanjut yang dapat dilakukan adalah mengadakan penyuluhan lanjutan dengan tema memberdayakan Ibu Rumah Tangga di dusun Pasekan Lor agar lebih produktif dan mandiri secara financial. Sebagai contoh dengan membentuk UMKM baru sehingga mampu meningkatkan penghasilan dan mendorong kemandirian ibu rumah tangga. Dengan adanya penyuluhan lanjutan diharapkan permasalahan mendasar dalam keuangan keluarga bisa lebih ditekan.

\section{Daftar Pustaka}

Bank Indonesia, (2013). Pengelolaan Keuangan. Jakarta: Grup Pengembangan Keuangan Inklusif Departemen Pengembangan Akses Keuangan dan UMKM Bank Indonesia.

Lestari, S. (2012). Psikologi Keluarga : Penanaman Nilai dan Penanganan Konflik dalam Keluarga. Jakarta: Kencana.

Mulyanti, D., \& Sahidillah, N. (2018). Pelatihan Perencanaan Keluarga bagi Ibu-ibu PKK Desa Cimenyan Kabupaten Bandung. Jurnal Abdimas BSI, 1 (2), 259-267.

Ridwan, S., \& Inge, B. (2003). Manajemen Keuangan. Jakarta: Literata Lintas Media.

Siagian, S. P. (2008). Manajemen Sumber Daya Manusia. Jakarta: Bumi Aksara.

Sukirman, H, R., S, D., \& P, A. (2019). Pengelolaan Keuangan Keluarga dalam Rangka Peningkatan Masyarakat Mandiri dan Berperan dalam Peningkatan Literasi Keuangan Indonesia (Otoritas Jasa keuangan). Jurnal Abdimas, 165-169.

Yohana, C. (2014). Pelatihan Mengelola Keuangan Sederhana bagi Pengusaha Kecil di Desa Cibadak. Jurnal Sarwahita, 67-70. 